\title{
The Perceptions of Five Years Old Group Students' about Scientists
}

\author{
Sümeyra Zeynep Et ${ }^{1}$, Esra Kabataş Memiş ${ }^{2}$ \\ ${ }^{1}$ Department of Educational Science, Kastamonu University, Kastamonu, Turkey \\ ${ }^{2}$ Department of Science Education, Kastamonu University, Kastamonu, Turkey \\ Correspondence: Esra Kabataş Memiş, Department of Science Education, Kastamonu University, Kastamonu, Turkey.
}

Received: November 22, 2016

Accepted: January 10, 2017 Online Published: January 12, 2017

doi:10.11114/jets.v5i2.2167

URL: http://dx.doi.org/10.11114/jets.v5i2.2167

\begin{abstract}
The purpose of this research is to reveal the perceptions of students of five years old group about scientists. The practice was implemented with 76 students having education in five-age group continuing to various nursery schools located in the center of Kastamonu province. Before starting the practice, the teacher asked the questions of "Who is the scientist?" and made them thought with the aim of ensuring the awareness of students against scientist. Afterwards, the researchers asked the students to narrate their pictures while they collect the drawings. The paintings were coded by the researchers by using the descriptive analysis method. The codification was made individually at first and then together with all the researchers with the aim of ensuring the reliability of research. In the light of collected information, it was generally seen in the pictures of students that the work environment of scientists is constituted by the space and world and their gender is generally men and also, there was a small number of women scientist profile. It was also determined that the students emphasized the extraterrestrial life and drew the scientists as similar to astronauts and they used space crafts and planets in their paintings. In another finding, scientists were seen as the people who mostly conduct research and use potion in general. Another attractive research finding is that; a small number of students draw the scientist as person who use computer and study lesson. In the light of these findings, it can be told that the students were affected extremely from their environment (the movies and cartoon they watched, their families, etc....).
\end{abstract}

Keywords: science, scientist, perception, draw a scientist test

\section{Introduction}

The countries aimed at growing all the citizens as scientific literate with the aim of having a strong future (MNE, 2005; 2013). The individuals to use this awareness are affected from science by staying the course of being a scientific literate and can affect science. Thus, a process in which the ideas affect the science and the science affect the ideas. The science literacy which is important both for the individuals and the societies was defined by various people or establishments in various periods in the light of objectives of education. National Science Teachers Union of America has defined the qualification of a person who is a science literate as "using the science and technology in solving daily life problems, having the ability of decision making, fluently discussing the ideas and activities as based on the evidences, questioning, creative thinking, reasoning and having rational conclusions (NRC,1996). In Turkey, the vision of education program of science lesson has been defined clearly as "growing all the students as science literate individuals" (MNE, 2013; p.3). Moreover, within the scope of program, the qualifications of a science literate person were defined as; having the essential information and scientific process abilities regarding science, responsible in solving the problems regarding social troubles, having the ability of creative and analytical thinking, searching and questioning the information and noticing as a result of researches, the mind power, creative thinking and conducted studies that the information may change. With a different point of view, Yore, Pimm and Tuan (2007), distinguished the science literacy to the titles which are related to the main and derived meanings by investigating the education reforms, syllabus and current studies. According to them, while the main meaning of science literacy contains the cognitive and metacognitive abilities, critical thinking, mental abilities, reading, writing, speaking, listening, understanding the descriptions and communications technologies; the derived meaning contains the main titles that are included in science education reforms. Main and derived meanings of science literacy are given in Table 1. These are interrelated processes. 
Table 1.Meanings of scientific literacy (Yore et al., 2007)

\begin{tabular}{ll}
\hline Fundamental Sense & Derived Sense \\
\hline Cognitive and metacognitive abilities & Understanding the big ideas and unifying concepts of \\
& science \\
Critical thinking/plausible reasoning & Nature of science \\
Habits of mind & Scientific inquiry \\
& Technological design \\
Scientific language & Relationships among science, technology, society, and \\
(including mathematical language) & environment (STSE) \\
Information communication technologies (ICT) & \\
\hline
\end{tabular}

The common ground of science program and these defined various meanings is the aim of growing the students as the individuals who can look with the eyes of scientists. This can be realized by having a positive image directed to the scientist (Kaya, doğan \& Öcal, 2008). When the body of literature is investigated, it is seen that there have been too many researches regarding the perception of individuals about science and scientists in the last fifty years. The essential point of most of these researches is to determine the perception of children for science (Finson, 2002) and to show that the children have stereotyped ideas by this means (Scherz \& Oren, 2006). It was stated in many studies that the children from various age groups have wrong ideas about scientific information (Kang, Scharmann \& Noh, 2004) and thus, there is the need for more information about the ideas and thinking of children on science and scientific information (Kıliç, 2010).

A great number of studies were also conducted in our country in which the scientist images of students were investigated (Buldu, 2006; Deniş Çeliker \& Erduran Avc1, 2015; Ekici, Doğan \& Kaya, 2007; Güler \& Akman, 2006; Nuhoğlu \& Afacan, 2007; Kaya, Doğan \& Öcal, 2008; Korkmaz \& Kavak, 2010; Oğuz-Ünver, 2010; Öcal, 2007; Yontar Toğrol, 2000). These studies were conducted with the work groups from various levels such as teacher candidates (Ağgül-Yalçın, 2012), high - schoolers (Akcay (2011), secondary school students (Kara and Akarsu, 2015; Nuhoğlu and Afacan, 2011; Türkmen, 2008) and pre-school students (Özel, 2012). As stated in the study, the perceptions of students regarding the images of scientists can be affected from many various sources. For example; scientist are symbolized generally with their visual aspects and attitudes in television and books. These environments include the students and thus, help in growing their own ideas for scientists (Deniş Çeliker \& Erduran Avc1, 2015). Especially in small ages, creating and developing the perceptions of students against science and scientists can be ensured by teachers reflecting their perceptions against science and scientist in class environment. Moreover, sometimes the students reflect the scientists as extraordinary people or legendary creatures (Çakmakçı, Tosun, Turgut, Örenler, Şengül \& Top, 2011) instead of realistic people and sometimes with the stereotypical ideas (Ekici, Doğan \& Kaya, 2007). In general, the stated ideas on stereotypical scientist are just like the people who work in laboratory which is full of technological devices and experiment materials, wear white coat and who is middle -aged, male and shock head. Chambers (1983)In the study made on 4800 children from United States, Australia and Canada, it was determined that the scientists are perceived generally as male and as people who wear laboratory coat, glasses, who has beard and shock head and who are busy with experiment materials. Similar results are given in many studies. It is very important for removing such stereotyped ideas to investigate the scientist images from early ages, to reveal the current conditions comprehensively and also to take the required precautions without losing any time (Küçük \& Bağ, 2012).

Thus, the purpose of this study is to reveal the perceptions of students from five - age group who have education in pre-school. Depending on this purpose, the perception of students against scientists was defined with the paintings. The mostly used tool in determining their perception about scientist is also painting. Painting is the narration, expression and reflection tool which is stronger than the statements which the children try to express with words (Temel \& Güllü, 2016).

\section{Method}

\subsection{Research Model and Study Group}

In this study conducted with the aim of determining the perceptions of student from the five - aged group against scientist, the qualitative research model was used. The study group of research is constituted by 76 students from five age group who continue to have education in two pre-schools in center of Kastamonu province in 2015 - 2016 education year. In determining the study group of research, the purposive sampling method was used by the researchers because of allowing the study on definite and unapproachable individuals or situations (Erkuş, 2013).

\subsection{Collecting the Data}

With the aim of determining the perception of students attending the research about the scientist, the "Draw a Scientist Test" developed by Chambers (1983) was used. The purpose of research was told to the students by researchers and their participation was ensured with their own consents. Then, $35 * 25$ size of drawing paper and 12 of dry paint set were 
distributed to the students with the aim of drawing and afterwards, the students were asked to draw the "scientist" in their imaginary world. This practice was implemented in one class hour. Within this duration, the researchers were present in the class for helping the students in providing required support (pencil sharpening, distributing the drawing papers, etc.) and preventing the students from affecting each When the students completed their drawings, the researchers made one on one interview with the children about drawings and asked them to narrate the paintings and took short notes regarding the drawings emphasized in paintings.

\subsection{Analysis of Data}

76 paintings gathered from the students attending to the research were analyzed in line with the content analysis method by researchers. As a result of conducted analysis, it was determined that there is no perception for scientists in drawings of 2 students and they were excluded from the study concept. The codifications were created by using the similar studies in literature. In addition, with the aim of increasing the reliability of codifications; the researchers made all the codifications individually at first and then collectively by comparison. The gathered findings were presented with frequency (f) analysis and samples of drawings of students.

\section{Results}

When the distribution of answers given by students against the question of "Who is scientist?", four categories were created. These four categories are gender, physical characteristics, work environment and research symbols. The findings for each category were given in separate titles.

\subsection{Gender of Scientist}

When the drawings are investigated, the findings regarding the gender of scientist are given in Table 1. As a result of the gathered findings, while 41 students $(54 \%)$ painted the scientist as male; 20 students $(26.3 \%)$ painted the scientists as female. While 9 of students $(11.8 \%)$ painted both the male and female scientists in their paintings; only 2 students $(2,6 \%)$ did not use ant figure regarding gender. The samples of student's drawings regarding the gender of scientist are given in Figure 1.

Table 1. Frequency distributions for gender

\begin{tabular}{ll}
\hline Gender & f \\
\hline Male & 41 \\
Female & 20 \\
Female/Male & 9 \\
Unspecified & 2 \\
\hline
\end{tabular}
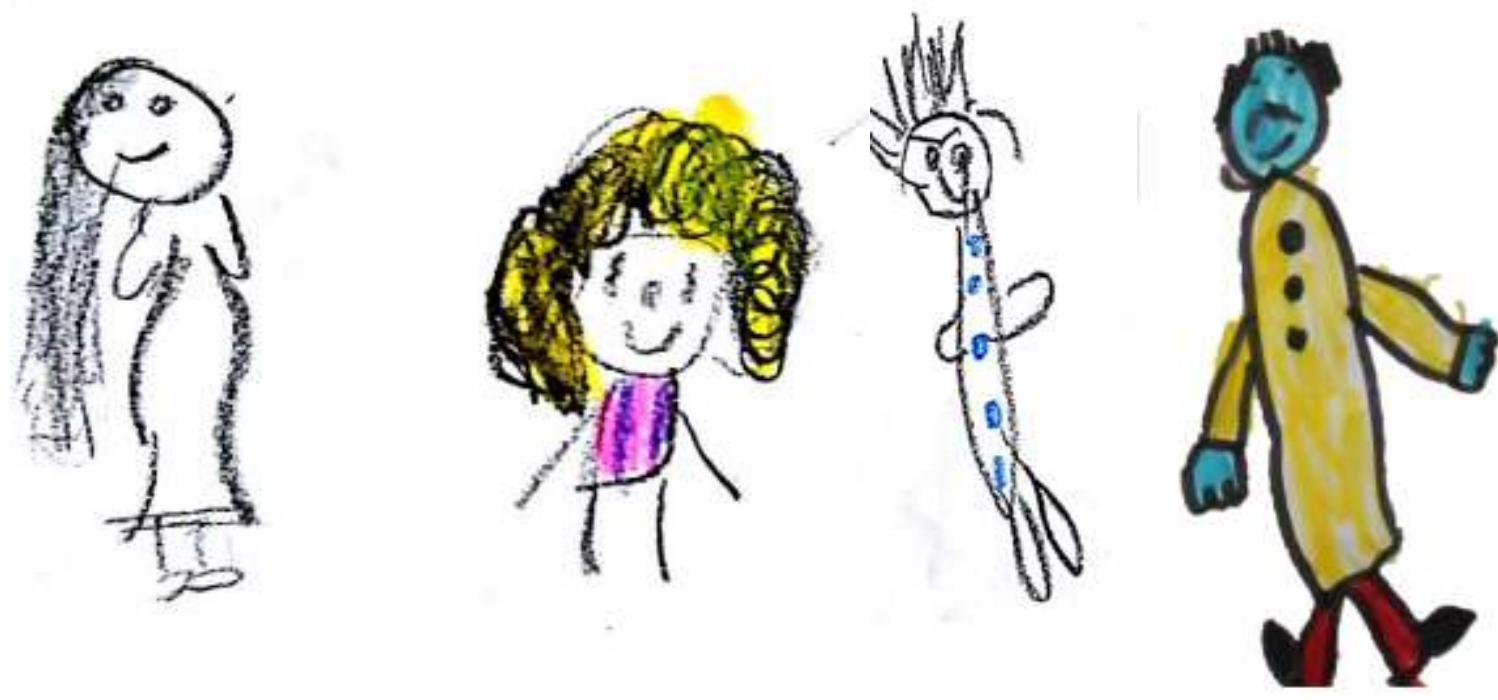

Figure 1. Gender of Scientist 


\subsection{Physical Characteristics of Scientist}

The distribution of physical characteristics of scientist painted by students in their drawings is given in Table 2. Physical characteristics are gathered under four distinct categories. These categories are the clothes, the head region, used accessories and the facial expression of scientist. When the clothes are investigated; it is determined that 22 students painted the scientists with daily clothes, 14 students painted them with laboratory coats, 3 students painted them with tie - bow tie - kerchief and 3 students painted them with astronaut clothes. When the head region is assessed; it is determined that; 20 students painted the scientist as bald, 21 students painted them with messy hair, 18 students painted them with long hairs, 13 students painted them as well - kept and 5 students painted them with fell hair. Another category created regarding the physical characteristic is the accessories used by scientists. When the drawings are examined, while 57 students did not put any accessories on scientists; 6 students perceived the scientists as people who wearing glasses; 7 students painted the scientist with accessories such as necklace, earing, buckle or helmet. An attractive finding is that; while more than half of the students (40 students) painted the scientist with happy facial expressions; 23 students did not use any expression and 4 students painted them with worried expression. Samples of students regarding the physical characteristics of scientist are given in Figure 2.

Table 2. Frequency distributions for physical characteristics

\begin{tabular}{lll}
\hline Physical characteristics & & f \\
\hline & Daily Clothes & 22 \\
Clothing Features & Laboratory Coats & 14 \\
& Tie - Bow tie - Kerchief & 3 \\
& Astronaut Clothes & 3 \\
\hline & Messy hair & 21 \\
& Bald & 20 \\
Head Region & Long hairs & 18 \\
& Well-groomed hair & 13 \\
\hline & Fell hair & 5 \\
Accessories & Necklace, Earing, Buckle, Helmet & 7 \\
& Glasses & 6 \\
Facial Expression & Unspecified & 57 \\
& Happy & 40 \\
& Worried & 4 \\
\end{tabular}
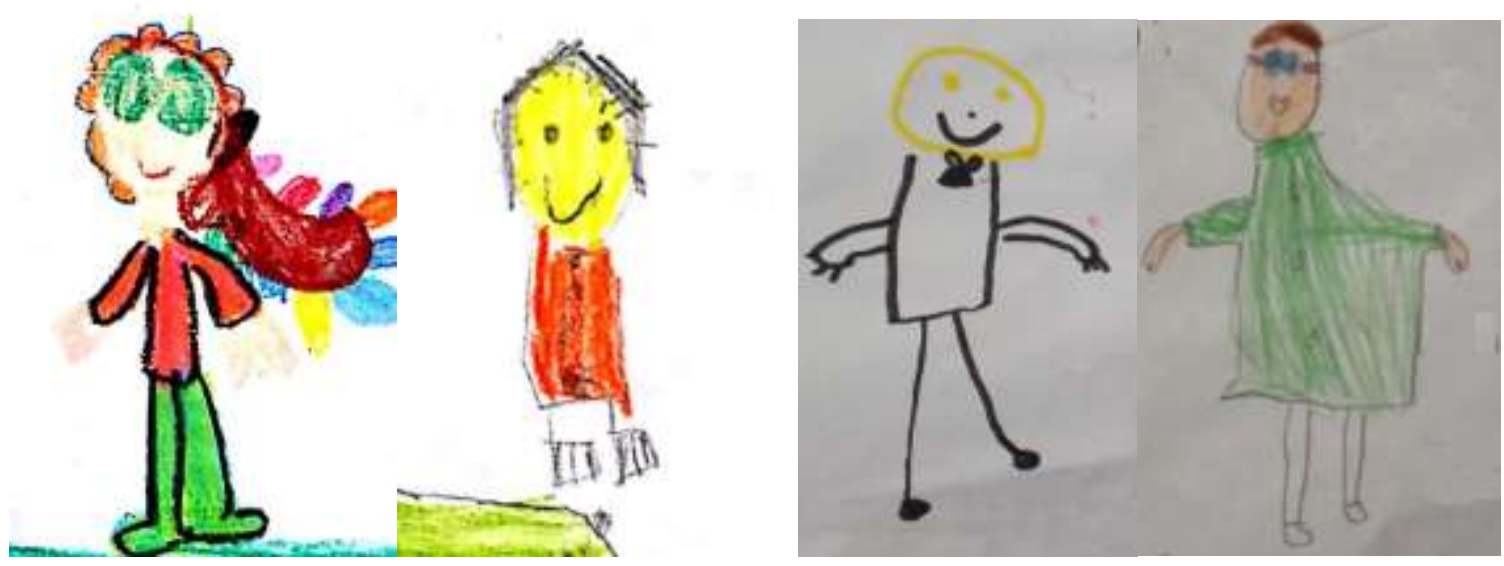

Figure 2. Physical Characteristics of Scientist

\subsection{Work Environment of Scientist}

As a result of research findings, it was seen that the work environment of scientists changes and that, 22 of students painted the scientists in nature; 12 of them did not make show any location; 11 of students painted the scientist science center, 9 of students painted them in room/office, 7 of students painted them in laboratory, 8 of students painted them in space, 3 of students painted them in home and 1 student painted them in faculty. The frequencies regarding the work environments of scientists are given in Table 3 and the sample drawings are given in Figure 3. 
Table 3.Frequency distributions of the work environment of scientist

\begin{tabular}{ll}
\hline Work Environment & f \\
\hline Nature & 22 \\
Science room / science center & 11 \\
Room / office & 9 \\
Space & 8 \\
Laboratory & 7 \\
Home & 3 \\
Faculty & 1 \\
Nonoriented & 12 \\
\hline
\end{tabular}
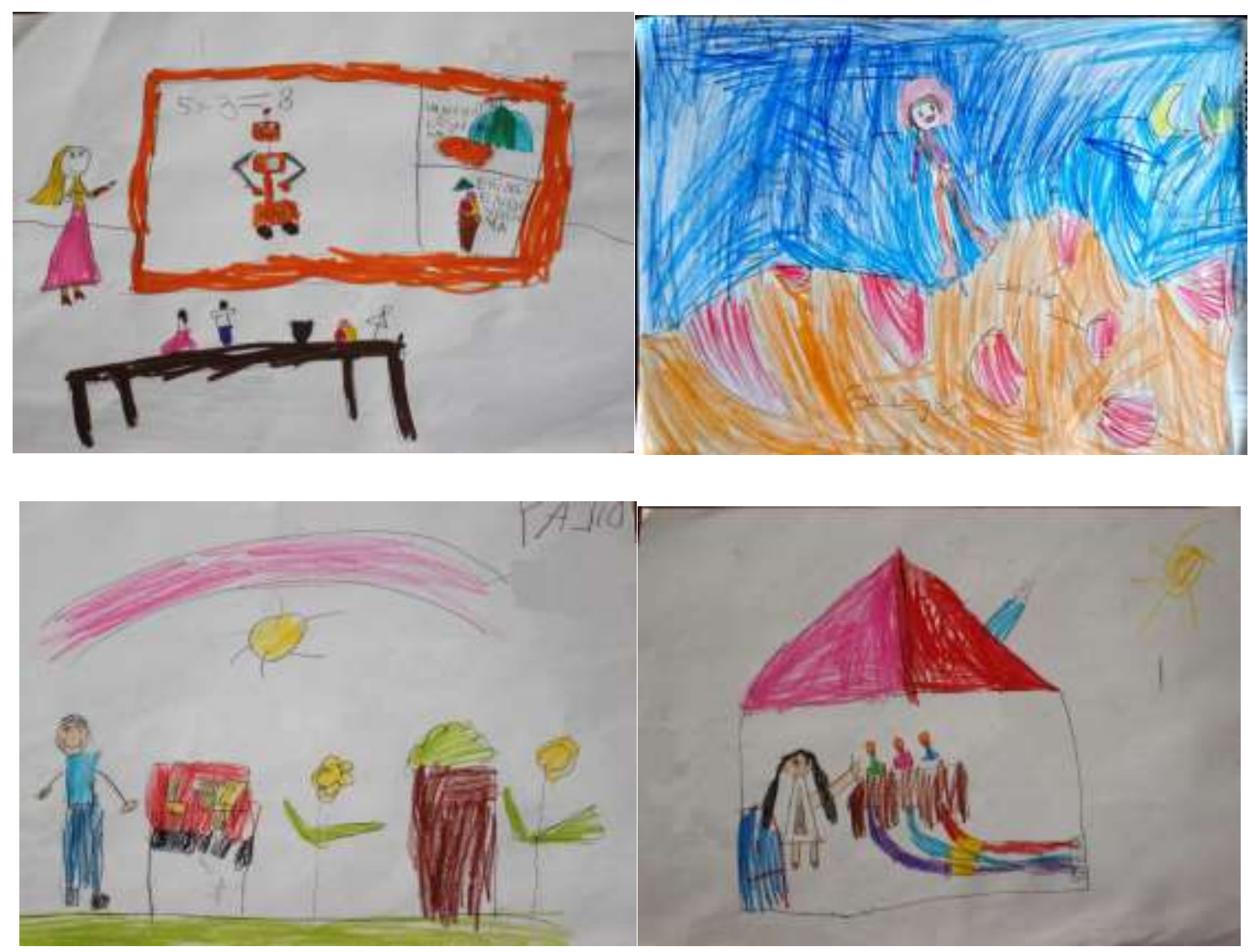

Figure 3. Work Environment of Scientist

\subsection{Research Symbols}

Another attractive category created in line with the gathered drawings is the research symbols in which the scientists are expressed with drawings. While the test tubes and potion are the research materials that were expressed by students; the animal figure was used only by one student. The research symbols exempted from these two groups are robots, technological tools, car, rocket/plane, flower/tree and planet. The research symbols used by scientists are given in Table 4 and the sample student drawings regarding these symbols are given in Figure 4. 
Table 4. Frequency distributions for research symbols

\begin{tabular}{ll}
\hline Research Symbols & f \\
\hline Potion & 26 \\
Test Tubes & 25 \\
Robot & 15 \\
Technological Tools & 12 \\
Car & 7 \\
Flowers / Trees & 5 \\
Rocket / Aircraft & 5 \\
Painting/ Drawing & 3 \\
Planet & 2 \\
Computer & 2 \\
Mirror & 2 \\
Rainbow & 1 \\
Shield & 1 \\
Animal & 1 \\
Volcano & 1 \\
\hline
\end{tabular}
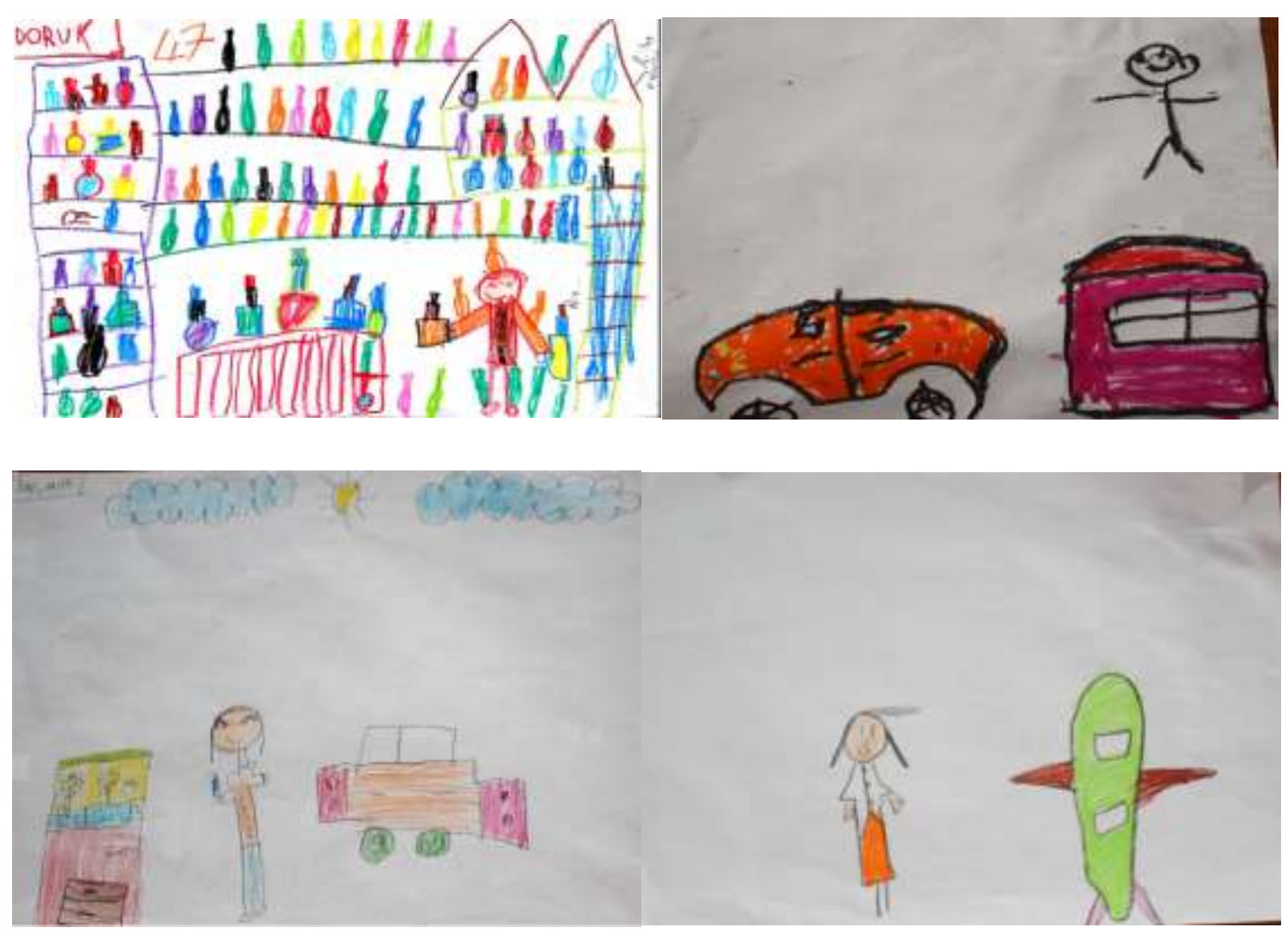

Figure 4. Research Symbols of Scientist

\section{Discussion and Conclusion}

The rapid economic, social, scientific and technological developments experienced in today's world have changed our life distinguishably. Today, the impact of scientific and technological developments on our lives is seen clearer than ever before. Globalization, international economic competition, rapid scientific and technological developments will continue to affect our lives in future (MNE, 2005). The way of the countries to keep pace with changing conditions is to grow the individuals who can create the information, know the paths to correct information, conduct scientific research and notably have the scientific thinking ability. The individuals who have these characteristic can be developed only with effective schools systems and the education to be given in these schools. When the implemented researches were investigated, it was determined that the students from various grades have wrong perceptions against the nature of science and against the scientist (Doğanay, Demircioğlu \&Yeşilpınar; 2014, Doğan Bora; 2005; Özbek; 2013, Kapancık; 2009) The way to be freed of these wrong perceptions is to give point of view to the students in each grade that science is a field which is always open for questioning, researching and changing. To this end, the pre-school education can be 
though as the first step in preventing these wrong perceptions. In the light of this information, it is very important to determine the scientist image in the eyes of students from five-age group.

In this study, it was tried to determine the images of students from five - age group about scientist. The drawings of students regarding their perception about scientist were assessed by gender, physical characteristics, research symbols and work environment. When the drawings were assessed by gender, it was seen that while 41 (54\%) of students participating the study painted the scientist as male; 20 of the students (26.3\%) painted the scientist as female. While 9 $(11.8 \%)$ of students showed both of the male and female scientists in their drawings; only 2 students $(2,6 \%)$ did not use any figure regarding the gender. This result is in parallel with the study conducted by Özsoy and Ahi (2014).In the study conducted with the students from primary school (1, 2, 3, 4, and 5. Class), it was determined that \%65.6 of students painted the scientist as male and \%22.5 of students painted the scientist as female. In the study of Toğrol Yontar (2000), \%72,5 of 443 primary school and high school students painted the scientist as male and $12,6 \%$ of them painted the scientist as female; in the research of Kara and Akarsu (2015), it was seen that 89 of 114 middle school (5, 6, 7 and 8. Class) students painted the scientist as male and 25 of them painted the scientist as female. Gathered results emphasizes that the scientist in the minds of students from various grades is male in general. As the reason of this, the wrong transmission in media and organs (cartoon, animation movies, scientist biographies, and news and TV series) as the science is an occupation only implemented by men and the wrong usage of "science men" instead of "scientist" can be stated. Moreover, within the scope of this study, the potion figures seen in the drawings of students show that they are generally impacted from media.

The drawings of students for scientist were investigated by physical characteristics, clothes, head region, accessory and facial expression. When the drawings of students, there is no decrease in the number of laboratory coats in terms of clothes and besides, it is an important result that there is no special cloth and there is the increase in daily cloth figures. While the result of this research is contrast with the researches implemented by Kara and Akarsu (2015) and Güler and Akman (2006); it is in parallel with the researches of Deniş Çeliker and Erduran Avcı'nın (2015).

In various researches implemented in our country, it is determined that the students generally perceive the scientist as person who has glasses, who is bald, who wears laboratory coat, who has beard of mustache, who works alone with chemical materials in laboratory, who is middle aged or aged and as men (Kara ve Akarsu, 2015; Korkmaz \& Kavak, 2010; Güler \& Akman, 2006). When these results are taken into consideration, another attractive result of research is that the students do not perceive the scientists as person who is bald, who wears glasses and laboratory coat and who is unhappy. The ideas of students and the scientists may have different physical appearances (well-kept hair, daily clothes, bow tie, and happiness), this may be interpreted as the indicator that this issue is perceived beyond the current classic perception.

When the drawings were investigated by work environment of scientists; it was seen that 22 of students painted the scientists in nature; 12 of them did not make show any location; 11 of students painted the scientist science center, 9 of students painted them in room/office, 7 of students painted them in laboratory, 8 of students painted them in space, 3 of students painted them in home and 1 student painted them in faculty. The results of this research is very important to show that the students perceive the scientists as people who also work outside the indoor areas; that the work environments are not limited with laboratories and that the students deem the science centers, offices, faculty and homes as venues where the scientists can work.

When the research results are assessed, it is seen that the perceptions of students regarding the research symbols used by scientists are different and mainly the potions and test tubes are used. Robots, technological devices, car, flower/tree, rocket /plane, picture, mirror, plate, computer and animal are the other valid research symbols. An attractive result gathered under this title is that; $1 / 3$ of students used the potion figure in their drawings. In these drawings, it can be told that the students perceived the scientist as people who generate potion and who is busy with magic. This result is in parallel with the study implemented by Özsoy and Ahi (2014).

Depending on the results of research, it is seen that the students are affected largely from notably cartoon and media channels. When the power of being affected from media and books is taken into account for children, the images used for scientists in these sources should be taken into consideration. Presenting the scientist as people who are involved in the situations created with concepts such as magic, spell and witchery or the people who individually implement such incidents is seen as the great barrier standing in front of the correct scientist and science perceptions. Another element who has the power of impact as much as the media and books is the teachers. Teachers are the greatest supports of individuals to take the first step in social life. Thus, the students may imitate their students with varying impacts in varying periods. In the light of this information, it is very important for teachers to abstain from current stereotypes in creating the correct scientist and science perception and thus, to have the correct information about this issue at first. Moreover, the teachers are expected to use more activities especially in in-class activities to generate the term of 
"scientist" and to help in gathering this perception. As stated in literature, when the results of researches implemented with the students from various grades are taken into consideration, it is seen that the students have a stereotyped perception about scientist. From this point of view, it is deemed as very important to determine the perceptions about scientist in early ages and to generate the planning that are well for making changing or development in current perceptions with the cooperation of family and school. Thus, it is though that this study is thought to provide important contributions to this literature.

\section{References}

[NRC] (1996). National science education standards. Washington, DC.

Ağgül, Y. F. (2012). Investigation of prospective teachers' ımage of scientist with respect to some variables. Elementary Education Online, 11(3), 611-628.

Akçay, B. (2011). Turkish elementary and secondary students' views about science and scientist. Asia Pacific Forum on Science Learning and Teaching, 12(1), 1-11.

Buldu, M. (2006). Young children's perceptions of scientists: a preliminary study. Educational Research, 48(1), 121-132. http://dx.doi.org/10.1080/00131880500498602

Çakmakci, G., Tosun, O., Turgut, S., Orenler, S., Sengul, K., \& Top, G. (2011). Promoting an inclusive image of scientists among students: Towards research evidence-based practice. International Journal of Science and Mathematics Education, 9(3), 627-655. https://doi.org/10.1007/s10763-010-9217-4

Chambers, D. W. (1983). Stereotypic images of the scientist: The draw a scientist test. Science Education, 67(2), 255-265. https://doi.org/10.1002/sce.3730670213

Deniş, Ç. H., \& Erduran, A. D. (2015). Scientist Perception of Primary School Students: How Does Attendance to Scientific Activities Affect Scientist Perception? Mehmet Akif Ersoy University Journal of Education Faculty, 36, 90-104.

Doğan, B. N. (2005). Investigating science teachers' and high school students' views on the nature of science in Turkey. Doctoral Thesis, Gazi University, Institute of Educational Sciences, Ankara.

Doğanay, A., Demircioğlu, T., \& Yeşilpınar, M. (2014). A need assessment study for an interdisciplinary curriculum about nature of science for prospective elementary teachers. Turkish Studies, 9(5), 777-798. https://doi.org/10.7827/TurkishStudies.6725

Ekici, F., Doğan, A., \& Kaya, O. N. (2007).Scientific images of primary school second graders (6th, 7th, 8th, and 5th graders). National Science and Mathematics Education Congress, Ankara.

Erkuş, A. (2013). Scientific research process for behavioral sciences. Ankara; Seçkin Publishing.

Eroğlu, B. (2012). A study about the nature of science effect on the preservice science teachers? Informal reasoning about global warming. Ph.D. Thesis, Gazi University, Institute of Educational Sciences, Ankara.

Finson, D. K. (2002). Drawing A Scientist: What We Do and Do Not Know After Fifty Years of Drawings. School Science and Mathematics. 102(7), 335-345. https://doi.org/10.1111/j.1949-8594.2002.tb18217.x

Güler, T., \& Akman, B. (2006). 6 year old children's views on science and scientısts. Hacettepe University Journal of Education, 31, 55-56

Kang, S., Scharmann, L. C., \& Noh, T. (2004). Examining students' views on the nature of science: Results from Korean 6th, 8th, and 10th graders. Sci. Ed., 89, 314-334. http://dx.doi.org/10.1002/sce.20053

Kapancik, E. (2009). A longitudinal study of pre-service chemistry teacher's views about the nature of science. Master Thesis, Gazi University, Institute of Educational Sciences, Ankara.

Kara, B., \& Akarsu, B. (2013). Determining of attitudes and the image of secondary school students about scientists. Journal of Science Education, 3(2), 90-116.

Kaya, O. N., Doğan, A., \& Öcal, E. (2008). Turkish elementary school students' images of scientists. Eurasian Journal of Educational Research, 32, 83-100.

Kılıç, Ş. (2010). Children's attıtudes and stereotypes towards science and scientists. Journal of Turkish Educational Sciences, 8(2), 439-455.

Korkmaz, H., \& Kavak, G. (2010) Primary school students' ımages of science and scientists. Elementary Education Online, 9(3), 1055-1079. http://ilkogretim-online.org.tr/vol9say3/v9s3m18.pdf 
Küçük, M., \& Băg, H. (2012). A comparıson of the 4 and 5. Grade students' scientıst 1mages. Bayburt University Journal of Education, 7(2), 125-138.

McMillan, J. H., \& Schumacher, S. (2006). Research in education: Evidence-based inquiry (6th ed.). Boston: Pearson.

Merriam, S. B. (2013). Qualitative research: A guide to design and implementation. (Trans. Edit.) Turan, S. Ankara: Nobel.

Ministry of National Education (2005). Primary science and technology course 6th grade curriculum. Ankara: Education and Training Board.

Ministry of National Education (2013). Science Lesson (6th, 7th, and 8th grades) Education Program, Ankara, Turkey

Nuhoğlu, H., \& Afacan, Ö. (2007). Evaluation of the primary school students' view about scientists. 16. Educational Sciences Congress, Tokat, Turkey.

Nuhoğlu, H., \& Afacan, Ö. (2011). Evaluation of the primary school students' view about scientists. Journal of Kırşehir Education Faculty, 12(3), 279-298.

Öcal, E. (2007). Identification and description of 6, 7, 8. secondary school student's scientist image and schema. Master Thesis, Gazi University, Ankara.

Oğuz-Ünver, A. (2010). Perceptions of scientists: a comparative study of fifth graders and fourth year student teachers. Necatibey Faculty of Education Electronic Journal of Science and Mathematics Education, 4(1), 11-28.

Özbek, D. (2013). The effect of the applications that were carried out within the scope of science technology and society course, on the perceptions of pre-service teachers toward understanding the aspects of nature. Master Thesis, Karadeniz Technical University, Institute of Educational Sciences, Trabzon.

Özel, M. (2012). Children's Images of Scientists: Does Grade Level Make a Difference? Educational Sciences: Theory and Practice, 12(4), 3187-3198.

Özsoy, S., \& Ahi, B. (2014). Images of scientists through the eyes of the children. Necatibey Faculty of Education Electronic Journal of Science and Mathematics Education, 8(1). 204-230.

Patton, M. Q. (2014). Qualitative research and evaluation methods. (Trans. Ed.) Bütün, M. \& Demir, S. B. Ankara: Pegem-A Publishing

Scherz, Z., \& Oren, M. (2006). How to Change students' images of science and technology. Sci. Ed., 90: 965-985. http://dx.doi/10.1002/sce.20159

Temel, C., \& Güllü, M. (2016). Draw a Physical Education Lesson. Education and Science, 41(183), 351-361. http://dx.doi/10.15390/EB.2016.5106

Türkmen, H. (2008). Turkish primary students' perceptions about scientist and what factors affecting the image of the scientists. Eurasia Journal of Mathematics, Science and Technology Education, 4(1), 55-61.

Yontar, T. A. (2000). Student 1mages of the scientist. Education and Science, 25(118), 49-57.

Yore, L. D., Pimm, D., \& Tuan, H. L. (2007). The literacy component of mathematical and scientific literacy. International Journal of Science and Mathematics Education, 5, 559-589. http://dx.doi:10.1007/s10763-007-9089-4

\section{Copyrights}

Copyright for this article is retained by the author(s), with first publication rights granted to the journal.

This is an open-access article distributed under the terms and conditions of the Creative Commons Attribution license which permits unrestricted use, distribution, and reproduction in any medium, provided the original work is properly cited. 